\title{
高温度における T形断面鋼柱のクリープ座屈 \\ CREEP BUCKLING OF STEEL TEE COLUMNS AT HIGH TEMPERATURES
}

\author{
古村福次郎*, 安部武雄**, 岡·部 猛***, 篠 原 保二**** \\ Fukujiro FURUMURA, Takeo AVE, Takeshi OKABE and Yasuji SHINOHARA
}

\begin{abstract}
The creep buckling behavior of steel tee columns was studied experimentally and theoretically at high temperatures. The tee column specimens with width-to-thickness ratio $b / t=10$ were subjected to various constant load with eccentricities at high temperatures from 500 to $550^{\circ} \mathrm{C}$, and all of them failed by local buckling of the tee stem. The lateral deflection and contraction curves of the columns versus time were obtained and it was clarified how the load, eccentricities and temperatures affected the creep buckling behavior of tee columns. The test results were also compared with the values of nonlinear analysis by the finite element method which adopted the mechanical model of structural steel at high temperature propesed by authors. Consequently the validity and efficiency of the present analytical method were examined by the experimental results.
\end{abstract}

Keywords : creep buckling, high temperature, steel column, local buckling, finite element method

\section{$\S 1$. 序}

火災時高温状態での鋼柱の耐荷性能は，高温で起こる 各種の座屈挙動のために常温時の耐荷性能よりもかなり 減少する。特に，鋼材温度が $500^{\circ} \mathrm{C}$ 以上に達するよう な場合においては，構造用鋼材は応力ーひずみ関係が低 下するばかりではなくクリープひずみが顕著に生じるよ うになるため, 圧縮荷重下にある柱材には大きなクリ一 プ変形を生じるようになり，クリープ変形挙動下の座屈 現象が部材崩壊の原因となる場合が考えられる。した がって, $500^{\circ} \mathrm{C}$ 以上の高温状態において鋼構造建築物の 耐火設計を合理的に実現するためには，高温クリープの 影響（時間のファクター）も無視できないものと思われ る。

このような観点から著者らは，先に文献1），2）にお いて, 種々の偏心距離で一定荷重を受ける $\mathrm{H}$ 形断面鋼柱 の高温クリープ座屈挙動の実験並びに解析を行い，その 性状を調べた。この研究では, 鋼柱のクリープ座屈挙動 を実験的に検討することの手始めとして, 試験体には極 厚の $\mathrm{H}$ 形断面を用い，柱部材が弱軸回りに変形するよう な偏心荷重を加え, 構面内の過度の変形が鋼柱のクリー プ座屈を誘発するように設定した。しかしながら，現実 の建築物では極厚断面の部材だけではなく, 高温クリー
プ変形時に局部座屈や曲げねじれ座屈を起こして崩壊に 至るような幅厚比, 細長比を持つ部材も使用されている。 したがって，鋼構造建築物の耐火設計をより現実的なも のとするためには局部座屈や曲げねじれ座屈の検討も必 要である。

近年，高温時の局部座屈挙動に関連して実験的，解析 的研究 ${ }^{3 / 25}$ が見られるが, 高温時の鋼柱に局部座屈が生 じてクリープ座屈を起こす場合を検討した研究は著者ら の知る限り行われていない。

本論文では，鋼柱部材が高温時のクリープ変形挙動下 で局部坐屈を生じて崩壊する場合の実験データを得るこ とを目的として，一定温度下で偏心圧縮荷重を受ける T 形断面鋼柱材の高温クリープ座屈実験を行う。また，板 要素を用いた有限要素法による熱弾塑性クリープ解析法 で本実験のシミュレーションを行い，局部座屈を伴う鋼 柱部材のクリープ座屈解析に対する解析法の妥当性およ び高温時の鋼材料データの有用性を確認する。

\section{§2. T形断面鋼柱の高温クリープ座屈実験}

Fig. 1 に示すように, H形断面鋼柱部材に偏心圧縮荷 重が加わり弱軸まわりに曲げモーメントが作用すると， 柱部材を構成するフランジ板要素は軸荷重と面内の曲げ

本論文は, 参考文献 8)，9）を加筆修正し, 取りまとめたものである。.

* 東京工業大学 教授. 工博

** 東京工業大学 助教授. 工博

*** 熊本大学 助教授・工博

**** 東京工業大学 助手. 工修
Professor of Tokyo Institute of Technology, Dr. Eng.

Associate Professor of Tokyo Institute of Technology, Dr. Eng. Associate Professor of Kumamoto University, Dr. Eng.

Research Associate of Tokyo Institute of Technology, M. Eng. 


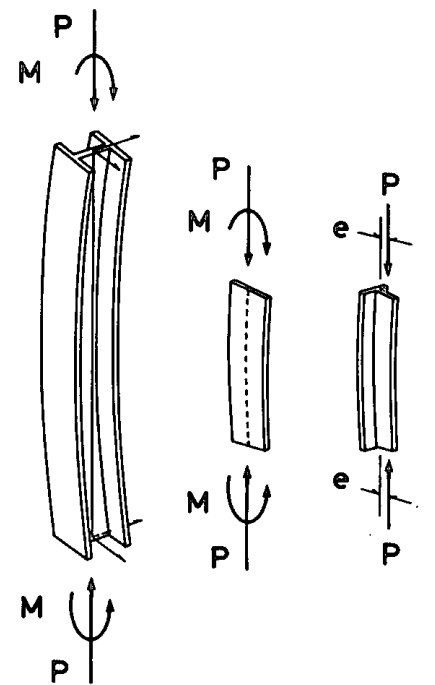

Fig. 1 弱軸曲げを受ける H 形断面鋼柱材

モーメント荷重とを同時に受けて板要素の面内方向に変 形を起こす。 $\mathrm{H}$ 形断面鋼柱部材のフランジ板要素は，こ のような変形下で面外へ座屈する可能性がある。

ここでは, 偏心圧縮荷重を受けて弱軸回りに変形する $\mathrm{H}$ 形断面鋼柱部材のフランジ板要素を理想化した試験体 として T形断面鋼柱部材を設定し, 高温クリープ座屈挙 動実験を行う。

\section{2-1 試験体}

実験に用いた試験体は，Fig. 2 に示す形状・寸法を持 つ 形断面鋼柱材 $(\mathrm{T}-99 \times 90 \times 9 \times 9)$ である。試験体 のウェブの幅厚比 $(b / t)$ は 10 であり, 実験装置の電気 炉の寸法の制約から，このように小型でかつT形断面の 試験体を用いる。
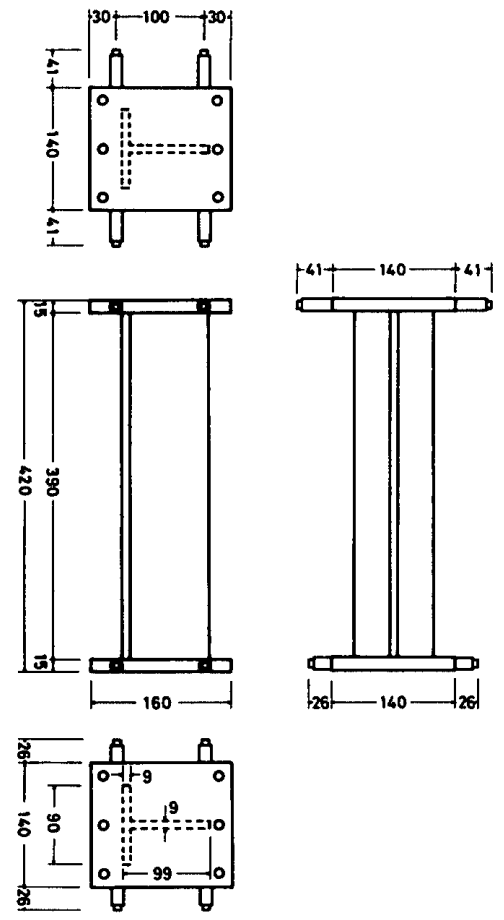

Fig. 2 T 形断面鋼柱試験体 $(\mathrm{T}-99 \times 90 \times 9 \times 9)$
この試験体は, 鋼種 SM 50A の $12 \mathrm{~mm}$ 厚の鋼板を溶 接して T形断面柱に組み立てた後, 所定の板厚に削り落 し, 両端に $15 \mathrm{~mm}$ 厚のエンドプレート（鋼種 MUKI） を溶接にて取り付けて製作したものである。実験時には， Fig. 3 に示すように試験体両端のエンドプレートに加力 治具が取り付けられ，部材両端の黒丸の位置にヒンジが セットされる。

使用鋼材のミルシートによる化学成分および常温時の 力学的性質を Table 1 - 2 に示す。

\section{2-2 実験方法}

実験装置は, 文献 1)，2）と同じく東京工業大学設置 のヴォールドウイン大型万能試験機および同機付属の円 筒形大型電気炉を用いた。したがって, 電気炉の寸法, ヒータの構造，温度の制御方法，試験体に荷重を伝達さ せるための圧縮装置そしてヒンジ等の治具類は文献 1),

2）に記載したものと同様である。

柱の変形も文献 1)，2）と同様に横たわみと材長方向 の伸縮を測定した。ただし，柱の伸縮に関しては Fig. 2，3に示すようにウェブの自由端付近とフランジ

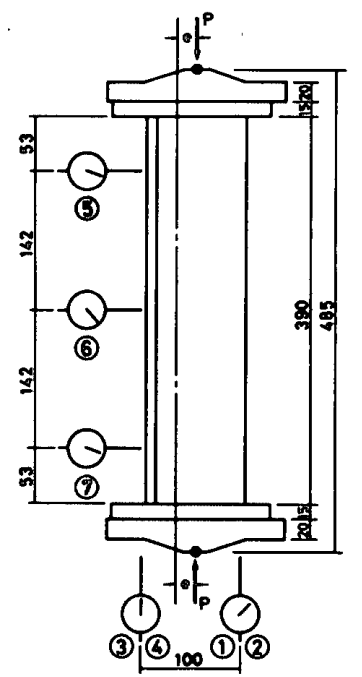

Fig. 3 ダイヤルゲージとヒンジ位置

Table 1 試験体鋼板の化学成分（ミル・シート値）（\%）

\begin{tabular}{|c|c|c|c|c|c|}
\hline $\begin{array}{c}\text { JIS } \\
\text { grade }\end{array}$ & $C$ & $S i$ & MD & $P$ & $S$ \\
\hline SH50A & 0.18 & 0.46 & 1.42 & 0.015 & 0.004 \\
\hline BORI & 0.11 & 0.18 & 1.47 & 0.005 & 0.002 \\
\hline
\end{tabular}

Table 2 試験体鋼板の機械的性質（ミル・シート値）

\begin{tabular}{|c|c|c|c|c|}
\hline \multirow{2}{*}{$\begin{array}{l}\text { JIS } \\
\text { grado }\end{array}$} & \multirow{2}{*}{$\begin{array}{l}\text { Dlate } \\
\text { thicknoss } \\
\text { (ad) }\end{array}$} & \multicolumn{3}{|c|}{ Tensile test (JISHo.5) } \\
\hline & & $\begin{array}{l}\text { Yield Strength } \\
\text { (kgt/ong) }\end{array}$ & $\begin{array}{l}\text { Tengile Strength } \\
\left(\mathrm{kgf} / \mathrm{an}^{2}\right)\end{array}$ & $\begin{array}{l}\text { Blongation } \\
\text { (g) }\end{array}$ \\
\hline SB50A & 12 & $42(38.8)$ & 58 & 38 \\
\hline BORI & 22 & 36 & 48 & 54 \\
\hline
\end{tabular}

(1) : Yield strength obtained fron the tensile tegt by authora 
付近の伸縮を別々に测定できるように，エンドプレート 上の水平方向に $100 \mathrm{~mm}$ 離れた点を検長 $405 \mathrm{~mm}$ で 4 点 測定した。

圧縮装置と柱変形測定装置の概要を Fig. 4 に示す。 試験体の試験温度は, $500,525,550^{\circ} \mathrm{C}$ の 3 種類とし, 各温度における作用荷重レベルは軸力比 $(\beta)$ で 0.25 0.4 の範囲とし，偏心距離は断面の図心位置よりウェブ の自由端に圧縮が加わる方向へ10〜25 mm の範囲で $5.0 \mathrm{~mm}$ 間隔で設定した。ここで， $\beta=P / A F$ であり， $P$ は軸力, $A$ は 形柱断面積， $F$ は鋼構造設計規準の $F$ 值 $\left(33 \mathrm{~kg} / \mathrm{mm}^{2}\right)$ である。奏験は, 一定温度下での一 定荷重試験と階段状変動荷重試験とを行った。全試験条 件を Table 3 に示す。

実験の手順は次のとおりである。

（1）試験体を電気炉内の所定位置にセットする。

（2）傾斜板および球座を用いて，試験体セット位置を 調整する。

（3）弾性変形の範囲内の荷重を作用させ, 試験体に貼 付された。8枚のワイヤストレインゲージでひずみを測 定する。

（4）測定されたひずみを計算值と比較し，良好なひず み分布が得られたなら次へ進む。ひずみ分布状態が悪い 場合は（2）にもどる。

（5）試験体の転倒を防ぐため，およそ $100 〜 250 \mathrm{~kg} の$

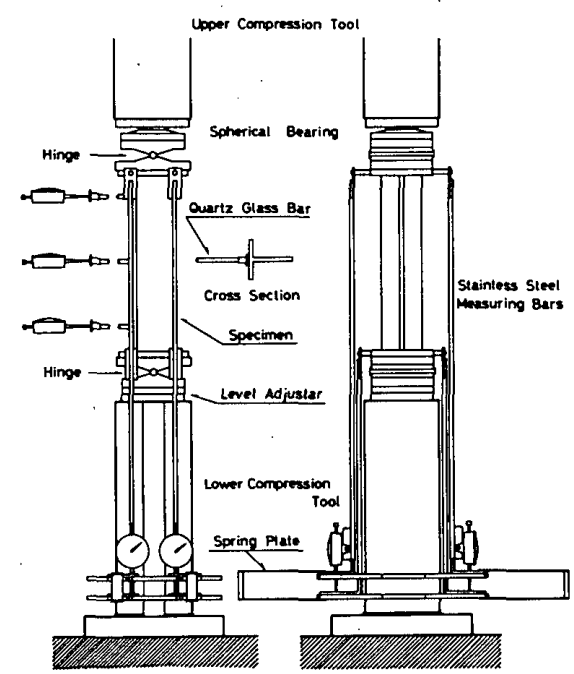

Fig. 4 加力装置と測定装置の概要

Table 3 実験条件

\begin{tabular}{|c|c|c|c|c|c|c|c|c|c|c|c|c|}
\hline \multirow{3}{*}{ (iin) } & \multicolumn{12}{|c|}{$I(c)$} \\
\hline & \multicolumn{4}{|c|}{500} & \multicolumn{4}{|c|}{525} & \multicolumn{4}{|c|}{550} \\
\hline & 10 & 15 & 20 & 25 & 10 & 15 & \begin{tabular}{|l|}
20 \\
\end{tabular} & 25 & 10 & 15 & 20 & 25 \\
\hline 0.25 & & & & & & & & & & & & 0 \\
\hline 0.30 & $\bullet$ & & & $\bullet$ & & & & 0 & - & 0 & 0 & \\
\hline 0.35 & & & 0 & $\dot{0}$ & & 0 & & & & & & \\
\hline 0.40 & & 0 & & & & 0 & & & & & & \\
\hline
\end{tabular}

$B=P /(A \cdot P)$

e: Bccontric distanco(n)

$P=A x$ ial load(tón)

$A=$ Sectional area $\left(c a^{2}\right)$

0 : Constant lood test

P: P-value =3.3(ton $\left./ c r^{2}\right)$

-: Step-rise change lood test

$P(\beta=1)=53.48$ ton: $T-89 \times 80 \times 9 \times \theta$
荷重を保持した状態で試験温度まで加熱し，比較的良好 な温度分布が得られるまで待つ。

（6）一定荷重試験の場合，載荷開始時に試験荷重レベ ルまで載荷した後，柱がクリープ座屈するまで試験荷重 を保持し続ける。変動荷重試験の場合, 載荷開始時に初 期の試験荷重レベルまで載荷して一定荷重に保持し柱を クリープ変形させ，その後所定の時刻において荷重を次 の試験荷重レベルまで素早く変化させ，最終的に柱がク リープ座屈するまで試験荷重を一定に保持し続ける。 2-3 実験結果

Fig. 5，6 に一定荷重試験の実験結果を，Fig. 7,8に

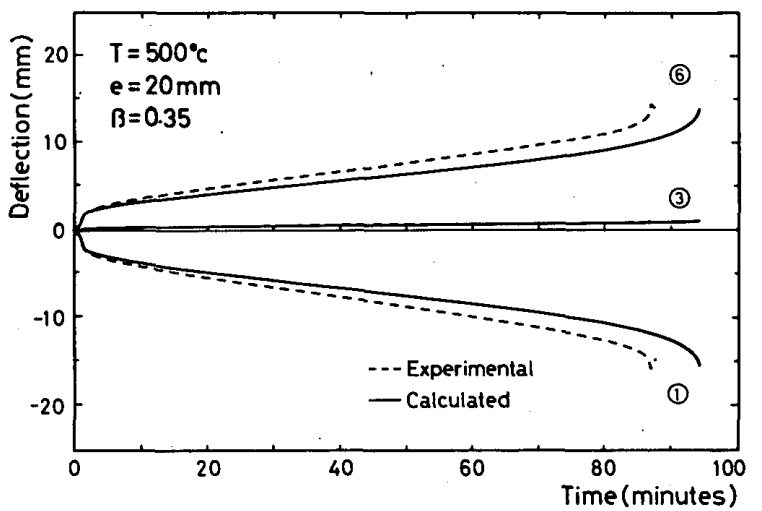

Fig. 5-a 変位の時刻歴 $\left(T=500^{\circ} \mathrm{C}, e=20 \mathrm{~mm}, \beta=0.35,-\right.$ 定荷重)

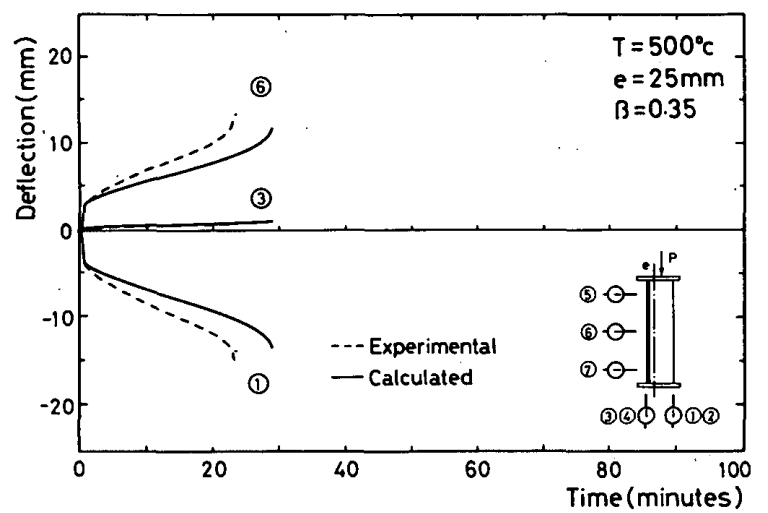

Fig. 5-b 変位の時刻歴 $\left(T=500^{\circ} \mathrm{C}, e=25 \mathrm{~mm}, \beta=0.35\right.$, 一 定荷重)

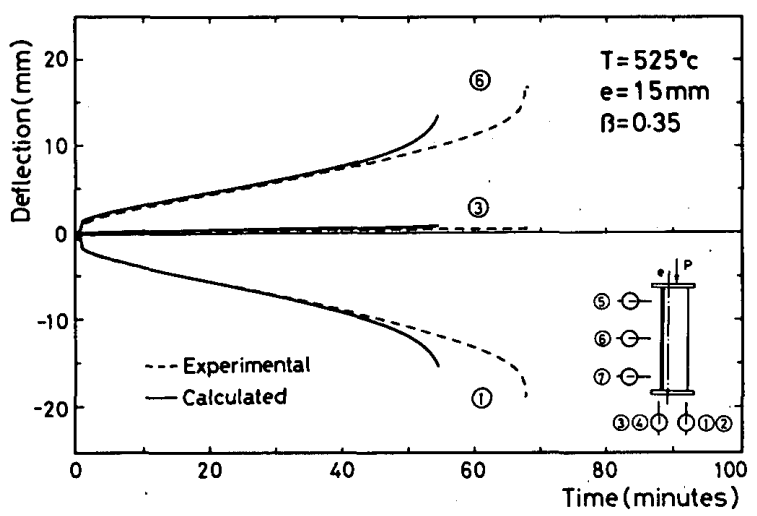

Fig. 5-c 変位の時刻歴 $\left(T=525^{\circ} \mathrm{C}, e=15 \mathrm{~mm}, \beta=0.35,-\right.$ 定荷重〉 


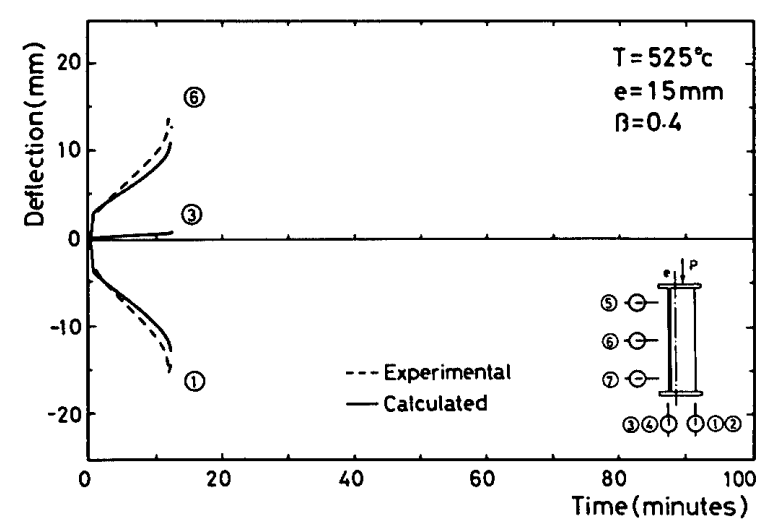

Fig. 5-d 変位の時刻歴 $\left(T=525^{\circ} \mathrm{C}, e=15 \mathrm{~mm}, \beta=0.40\right.$, 定荷重)

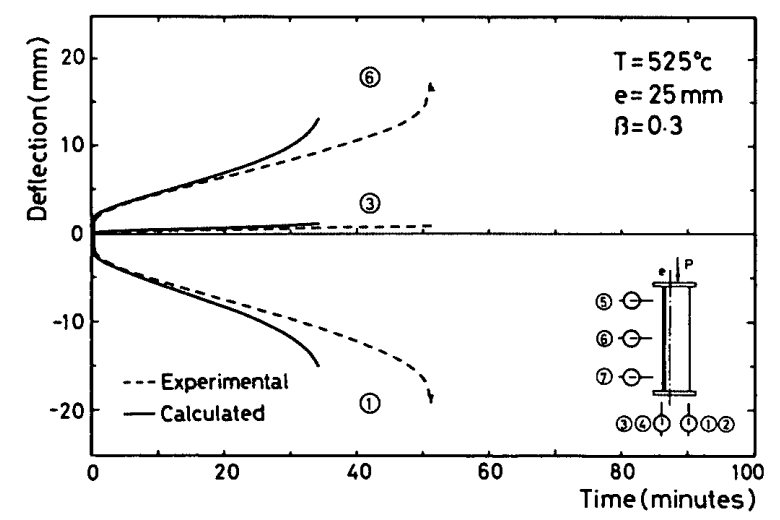

Fig. 5-e 変位の時刻歴 $\left(T=525^{\circ} \mathrm{C}, e=25 \mathrm{~mm}, \beta=0.30\right.$, 定荷重)

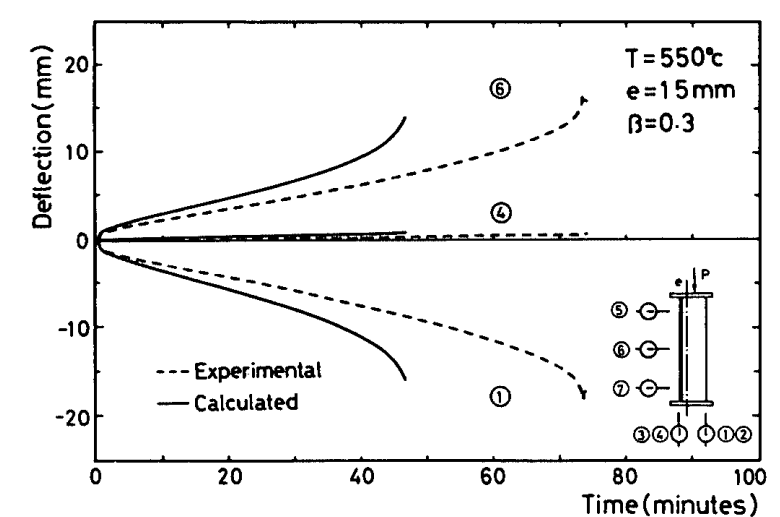

Fig. 5-f 変位の時刻歴 $\left(T=550^{\circ} \mathrm{C}, \quad e=15 \mathrm{~mm}, \beta=0.30,-\right.$ 定荷重)

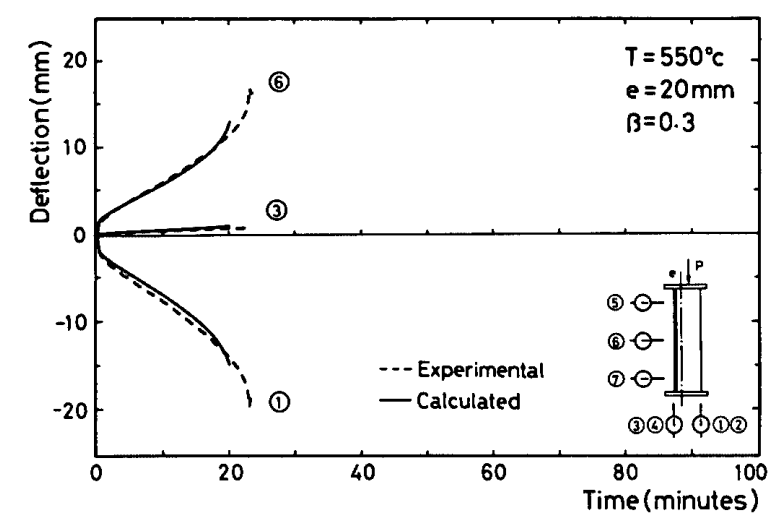

Fig. 5 -g 変位の時刻歴 $\left(T=550^{\circ} \mathrm{C}, e=20 \mathrm{~mm}, \beta=0.30,-\right.$ 定荷重)

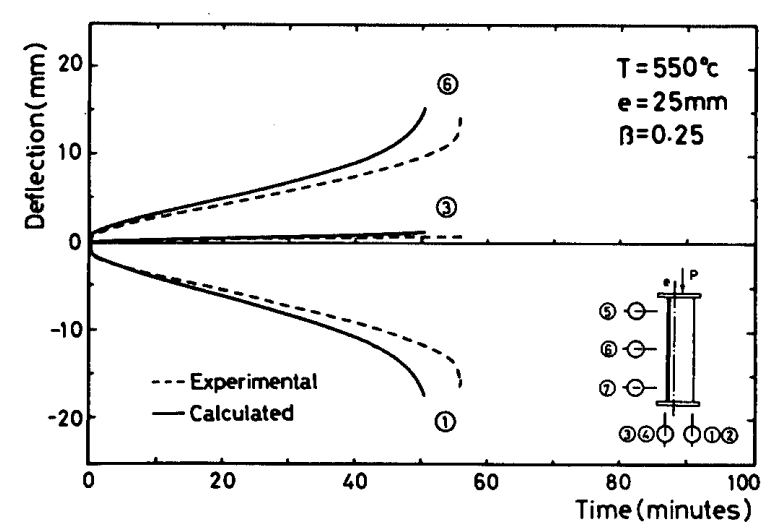

Fig. 5-h 変位の時刻歴 $\left(T=550^{\circ} \mathrm{C}, e=25 \mathrm{~mm}, \beta=0.25,-\right.$ 定荷重）

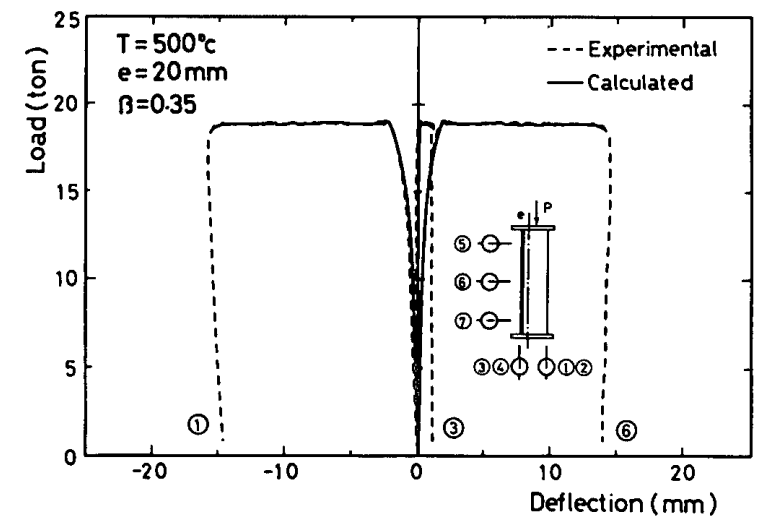

Fig. 6-a 荷重-変形関係 $\left(T=500^{\circ} \mathrm{C}, \quad e=20 \mathrm{~mm}, \quad \beta=0.35\right.$, 一定荷重）

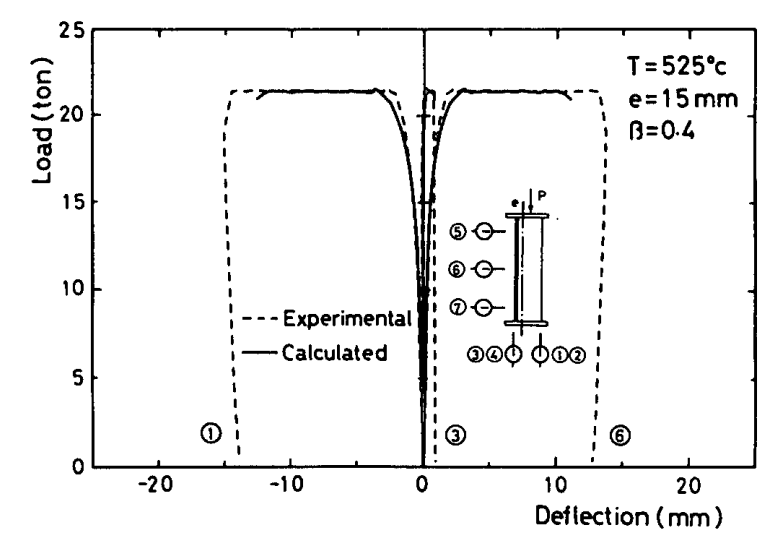

Fig. 6-d 荷重-変形関係 $\left(T=525^{\circ} \mathrm{C}, \quad e=15 \mathrm{~mm}, \beta=0.4,-\right.$ 定荷重)

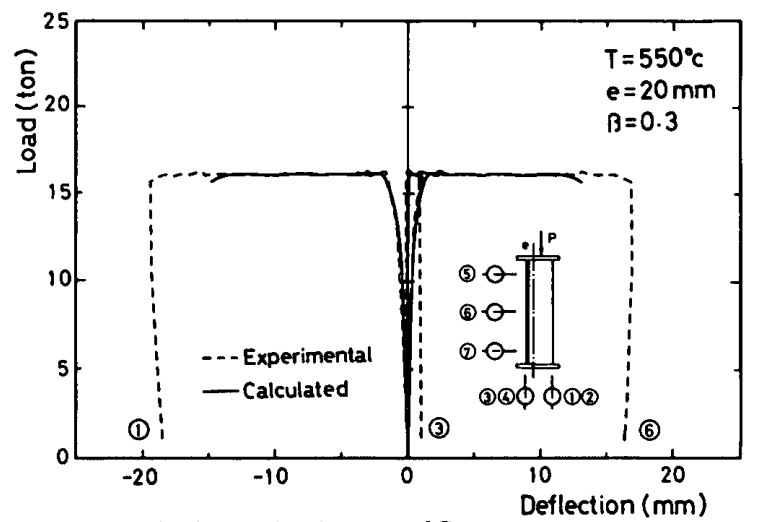

Fig. 6-g 荷重-変形関係 $\left(T=550^{\circ} \mathrm{C}, \quad e=20 \mathrm{~mm}, \beta=0.3,-\right.$ 定荷重) 


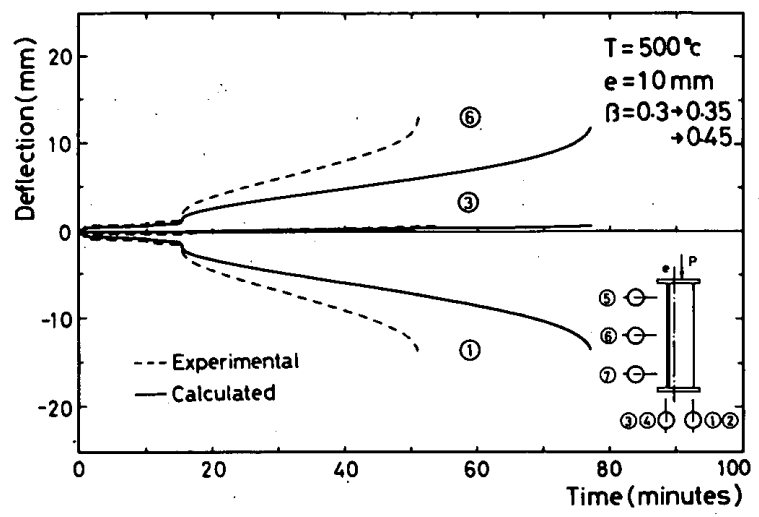

Fig. 7-a. 変位の特刻歴 $\left(T=500^{\circ} \mathrm{C}, \quad e=10 \mathrm{~mm}, \beta=0.3 \rightarrow\right.$ $0.35 \rightarrow 0.45$; 階段状変動荷重)

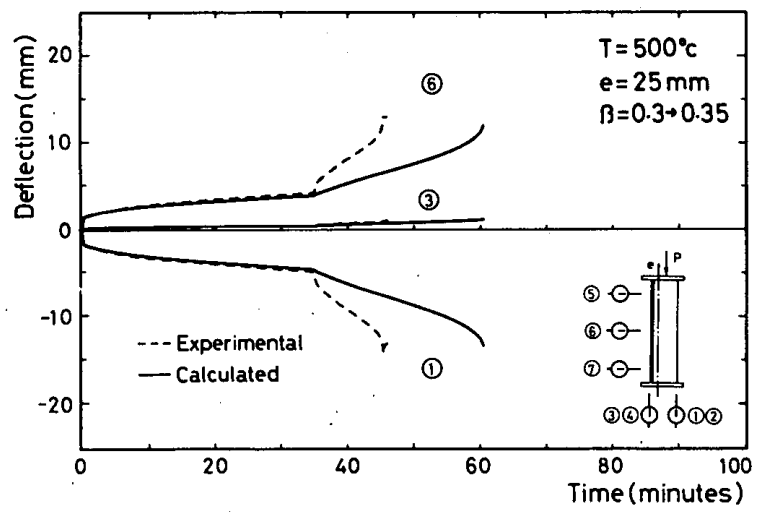

Fig. 7-b 変位の時刻歴 $\left(T=500^{\circ} \mathrm{C}, e=25 \mathrm{~mm}, \beta=0.3 \rightarrow 0.35\right.$, 階段状変動荷重）

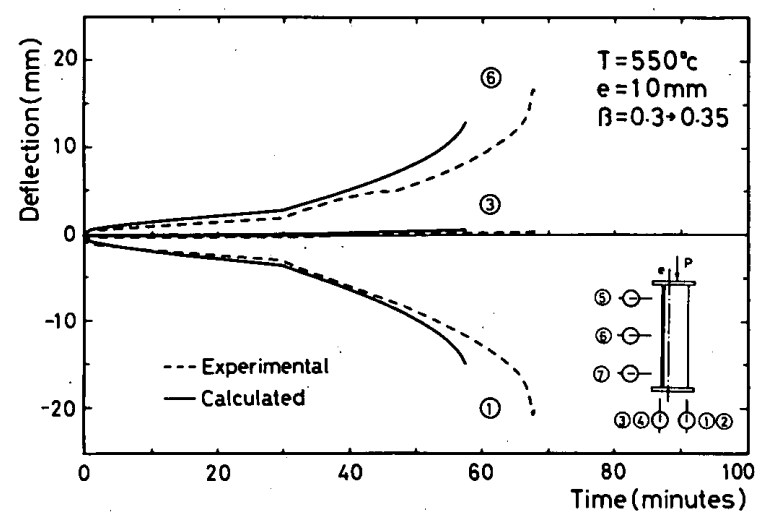

Fig. 7-c 変位の時刻暦 $\left(T=550^{\circ} \mathrm{C}, e=10 \mathrm{~mm}, \beta=0.3 \rightarrow 0.35\right.$, 階段状変動荷重)

変動荷重試験の実験結果をそれぞれ破線で示した。また, 実験後の試験体の残留変形をPhoto. 1 に示す。

Fig. 5,7は柱の中央たわみ(6)および材長方向伸縮(1) (3)等の時刻歴を示しており,Fig. 6, 8 は横軸を変位(1) (3)6, 縦軸を荷重 $P$ にして荷重-変形関係を表している。 一般に，鋼柱の横たわみおよび伸縮は，鋼材の第一期 クリープの影響により,クリープ試験の初期載荷段階に, かなり急速に增加する。その後, 変位速度がほぼ一定の 期間があり, 再び突然に変位が増加し始めて荷重が保持 できなくなる。

実験結果から明らかなように，横たわみ(6)が約 10

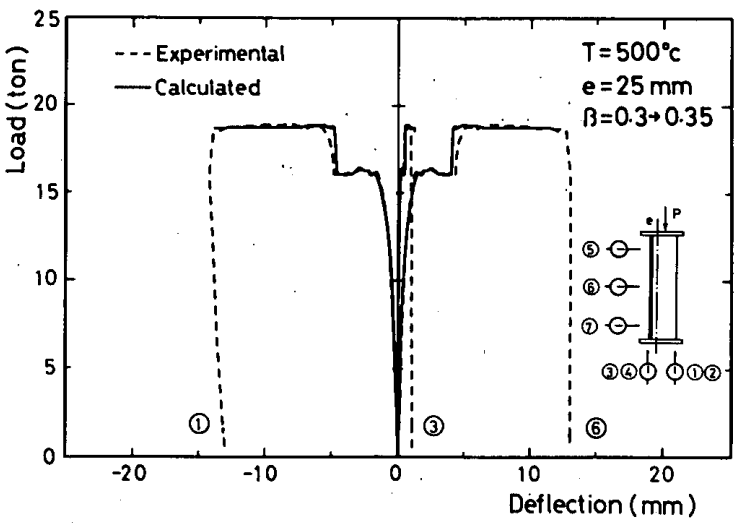

Fig. 8-b 荷重-変形関係 $\left(T=500^{\circ} \mathrm{C}, e=25 \mathrm{~mm}, \beta=0.3 \rightarrow\right.$ 0.35 , 階段状変動荷重)

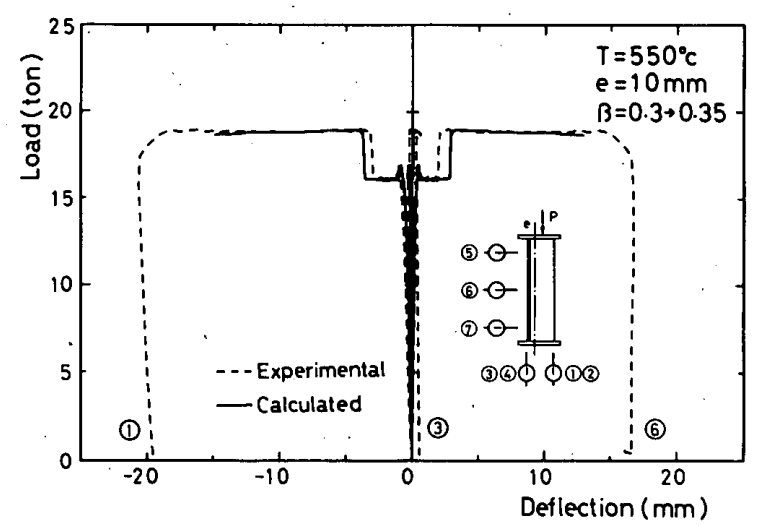

Fig. 8-c 荷重-変形関係 $\left(T=550^{\circ} \mathrm{C}, \quad e=10 \mathrm{~mm}, \beta=0.3 \rightarrow\right.$ 0.35 , 階段状変動荷重)

$\mathrm{mm}$ を超えると, 変位速度は加速度的に増加し, クリ一 プ座屈する。また， T形断面材のウェブ自由端付近の伸 縮量(1)は,フランジ付近の伸縮量(3)等に比較して大きい。 なお，ウェブ付近の伸縮量が急激に変化するとともに荷 重が保持できなくなっている。

これらの図から明らかなように， T形断面材のクリー プ座屈挙動は, 温度, 作用荷重, 偏心距離に大きく影響 される。

文献 1)，2）で行った極厚 $\mathrm{H}$ 形断面柱の高温クリープ 座屈実験の結果と本実験のそれを比較すると, 変位速度 がほぼ一定のクリープ変形状態から，たわみが急增を始 めて荷重を維持できなくなるまでの時間が短いようであ る。これは，文献 1)，2）の実験では柱部材の面内の曲 げ変形が過大となって部材崩壊が起こるのに対して, 本 実験では T形断面材のウェブ板要素の面外の局部座屈が 原因となり突然に部材崩壊が起こるためと思われる。

Photo. 1 より実験後に試験体に残留している変形状 態が分かる。ウェブ自由端の面外の残留変形は， $T=$ $500^{\circ} \mathrm{C}, e=10 \mathrm{~mm}, \beta=0.3 \rightarrow 0.35 \rightarrow 0.45$ の場合を除 き他のほとんどのものが両端固定条件の 2 波逆対称座屈 形状である。なお， $T=500^{\circ} \mathrm{C}, e=15 \mathrm{~mm}, \beta=0.4$ の 場合は, クリープ座屈が起こる以前に実験を中止したも のであり,試験体には面内方向変形のみが残留している。 

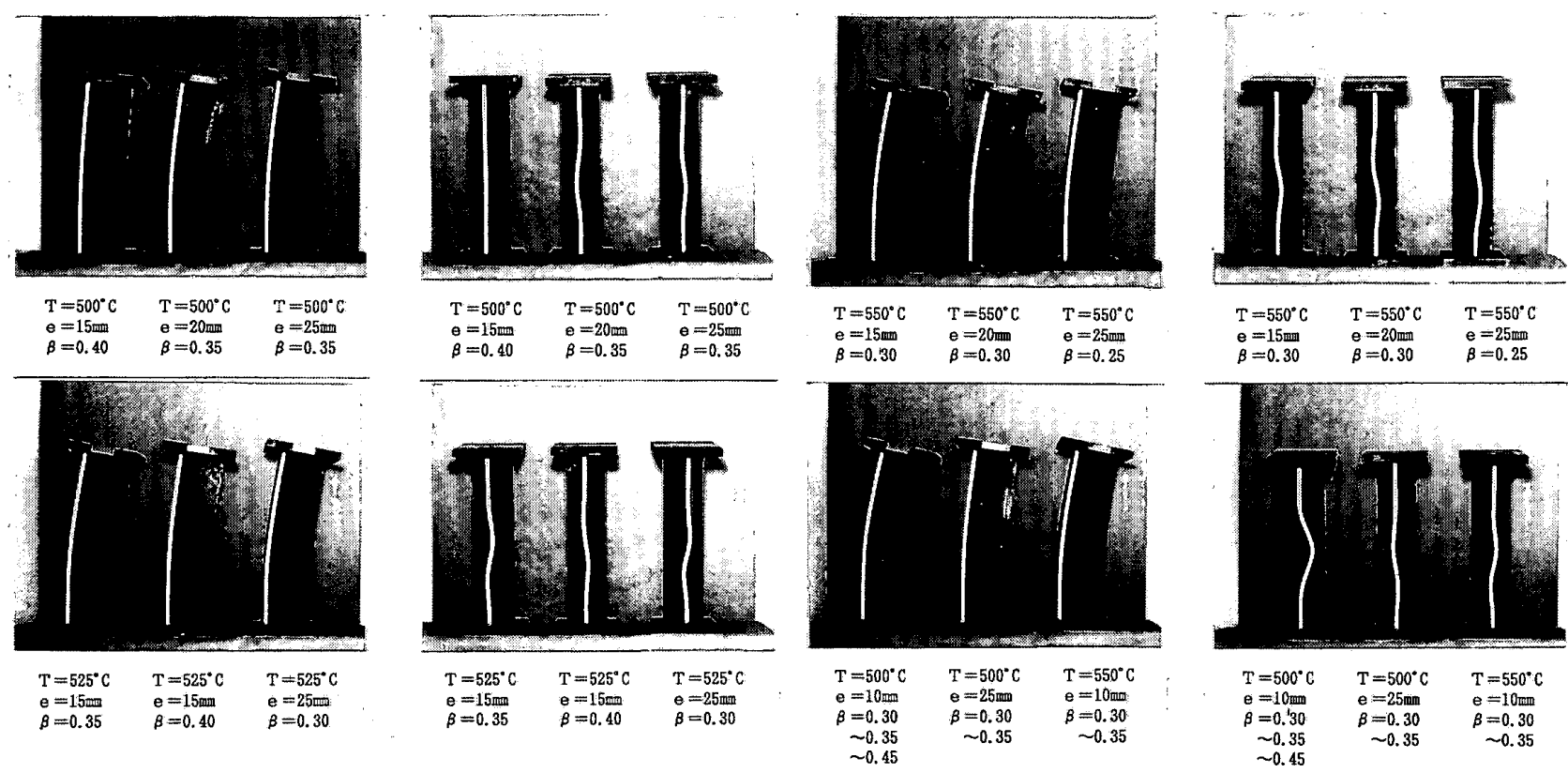

Photo. 1 実験後の試験体の残留変形

\section{§3. T形断面鋼柱部材の高温クリープ座屈挙動解析}

ここでは前節で示した T形断面鋼柱のクリープ座屈実 験を数値解析法を用いてシミュレートし, 実験結果と解 析結果との比較から, 解析法の妥当性を確かめる。

3-1 解析方法

Fig. 5, 6, 7, 8や Photo. 1 に見られるように，T形断 面鋼柱材は高温状態で偏心圧縮荷重を受けると, 初めに 部材全体としての面内の曲げクリープ変形を起こし, 最 終的にはウェブ板要素が面外方向へ座屈することにより 崩壊する。このような崩壊に至るまでの実験挙動を数值 解析法によってうまくシミュレートするためには，まず 最初に柱材の面内の曲げ変形挙動を精度良くとらえるこ とが必要であり, 同時にウェブ板要素の高温での局部座 屈挙動を評価する必要もある。

ここでは，著者らが先に文献 4) で示した鋼平板の高 温挙動解析法に改良を加えてT形断面柱の解析法を開発 し, 高温クリープ座屈挙動解析を行う。したがって, 文 献 4）で用いた鋼材の高温挙動をモデル化する仮定や板 材の理論に関する基本的な仮定は本解析においても同様 に用いる。

しかしながら, 文献 4）で示した解析法は面内圧縮を 受ける単一鋼平板の高温時挙動を解くために開発したも のであるため, 本論文の T形断面柱材の解析に適用しよ うとする場合, 二つの問題点がある。最初の問題点は, 文献 4）で用いた三角形有限要素には面内の回転を表す 自由度 $\theta_{z}$ が考慮されていない点である。T形断面柱の 試験体はFig. 9 左図に示すように鋼板で立体構成され ており, 文献 4）の有限要素ではこれを直接的に表現す ることができない。

この点に関しては試験体の方を Fig. 9, 10,11 に示す ような理想化した解析モデルとすることで対処する。

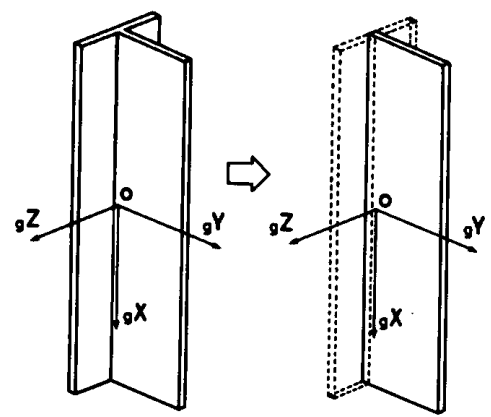

Fig. 9 試験体のモデル化
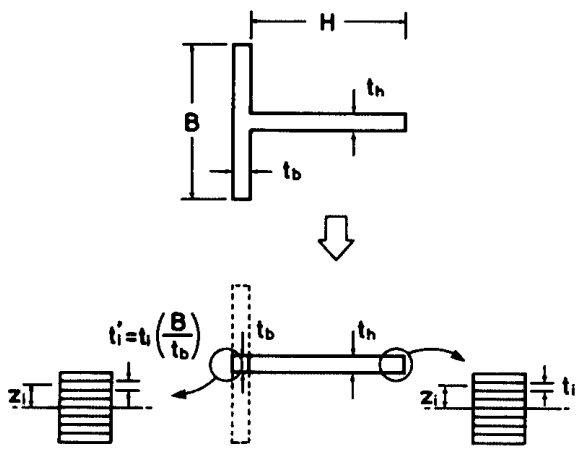

Fig. 10 試験体断面の解析モデル

Fig. 9, 10, 11 の解析モデルは, 全体座標系 $\theta_{z}$ 方向の モーメントの不平衡を無視し， T形断面材のウェブ，フ ランジともに自由度 $\theta_{z}$ を持たない ${ }_{g} X{ }_{g} Y$ 平面上の三角 形板要素で表されている。試験体のフランジ部分は Fig. 9，10に示されているように元々は ${ }_{g} X-{ }_{g} Z$ 平面に 平行に配置された $B \times t_{b}$ の矩形断面であるが, 解析乇 デルでは寸法 $B$ を ${ }_{g} Z$ 軸方向に $t_{b}$ に圧縮し, 面積 $B \times$ $t_{b}$ を $t_{b} \times t_{b}$ の正方形断面に集中させている。すなわち, Fig. 10 下図の解析モデルのフランジ部分の板要素の ${ }_{g} Z$ 軸方向の板厚は $t_{b}$ とするが, 計算上はフランジ板要素 の断面積は $B \times t_{b}$ とする。 


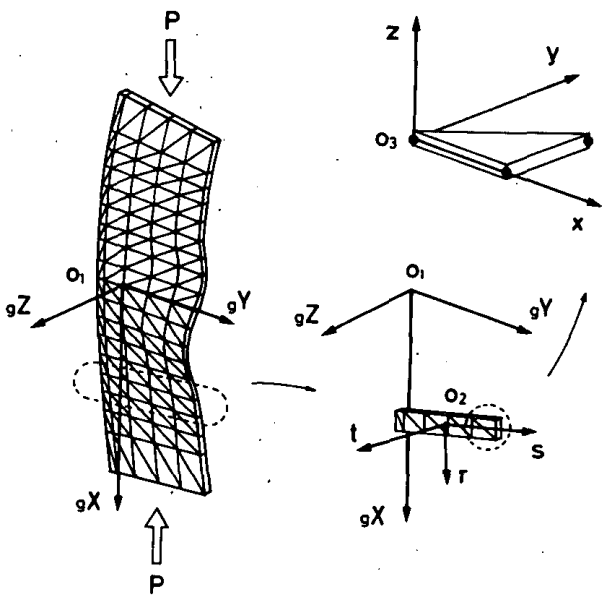

Fig. 11 要荎分割と三つの座標系

このように解析モデルと試験体の間でフランジ断面の ${ }_{9} Y$ 軸方向の座標位置と面積値を等しくし, なおかつ, 解析モデルのフランジ断面の ${ }_{g} Z$ 軸方向の板厚を $t_{b}$ と することにより， Т 形断面柱の ${ }_{g} X{ }_{-} Y$ 面内での曲げ変 形に対する抵抗力と ${ }_{g} Z-{ }_{g} Y$ 面内での稀じれ変形に対す る抵抗力との二つを解析モデルと試験体の間でほぼ等価 にすることができる。

なお，T形断面柱試験体のエンドプレートと試験体に 取り付けられた加力治具は一体のものと仮定し, 試験体 のT形断面部分のフランジ幅 $B(90 \mathrm{~mm})$ とウェブの幅 $H+t_{b}(99 \mathrm{~mm})$ 並びに ${ }_{g} X$ 方向の長さ $47.5 \mathrm{~mm}$ を辺長 とする立方体の鋼製ブロックとみなし，Fig. 11 左図の 解析モデルの上下端の一列の有限要素帯で表現する。し たがって，この板有限要素の ${ }_{g} Z$ 方向の長さ，つまり板 要素の板厚は $90 \mathrm{~mm}$ である。

また, 解析モデルの支持条件は以下のように設定する。 ます最初に， T形断面柱試験体のエンドプレートと試験 体に取り付けられた加力治具を表現する鋼製ブロック部 分は ${ }_{g} X-{ }_{g} Y$ 平面内の移動のみが許されるようにブロッ クを構成する節点の ${ }_{g} Z$ 軸方向の変位と ${ }_{g} X,{ }_{g} Y$ 軸回り の回転を拘束する。また，図中雨白矢印 $P$ の先端に位 置する加力点の節点は ${ }_{g} X$ 軸方向にのみ変位することが できるように， $g_{g} Y$ 軸方向の変位も拘束する。次に， Photo. 1 に示した残留変形を考慮して，T形断面柱材 は $g Y$ 軸回りに逆対称変形をするものと仮定し，数值計 算にはFig. 11 左図の柱材の上半分を用いるとともに， ${ }_{g} Y$ 座標軸上に位置する節点は ${ }_{g} Y$ 軸方向変位と ${ }_{g} Y$ 軸 回りの回転のみが許されるように ${ }_{g} X,{ }_{g} Z$ 軸方向の変位 と ${ }_{g} X$ 軸回りの回転とを拘束する。最後に, 試験体のフ ランジ板要素は寸法から判断して ${ }_{g} Z$ 軸方向の曲げ変形 に対する抵抗力は大きいので，T形断面柱材のフランジ 板材とウェブ板材の結合部分の節点は ${ }_{g} Z$ 軸方向へはほ とんど変位しないものと思われる。しかしながら，解析 モデルにおいてはフランジ幅を ${ }_{g} Z$ 軸方向に愿さ $t_{b}$ に 玨縮している関係から ${ }_{g} Z$ 軸方向の曲げ変形に対する抵
抗力が奏際の試験体に比較して小さくなっている。そこ で, 解析モデルのフランジ板材とウェブ板材の結合節点 は $g Z$ 軸方向には変位しないように拘束する。

以上のように簡略化した解析モデルを用いて計算を行 う理由は，主に次の二点を考虑したものである。

1) 本論文で示す T形断面鋼柱材の高温クリープ座屈実 験では，ウェブ材の座屈が顕著に起こり，フランジ材は ウェブ材の変形に対して拘束材として働いており，両者 の連成座屈的挙動は見られないので, あえて立体構成さ れたモデルを用いて解析を行う必要はない。

2）この種の解析法では一般に膨大な計算量が必要とな る。したがって，節点の自由度ならびに解析モデルを構 成する有限要素数を可能な限り娍し，計算量の娍少を計 ることが数值解析を経済的に実行する上で有効である。

二つ目の問題点は, 文献 4) で用いた三角形有限要素 は面内変形に対して一定ひずみの三角形有限要素を用い ていることである。この種の有限要素を用いて部材全体 の曲げ変形を精度良くとらえることは困難である。この 問題に対して，山田はが 要素に曲げ変形を考慮した補正関数を導入し，部材全体 の曲げ変形解析の精度を上げることを提案している。こ こでもこの方法を用いることにして，有限要素内の変位 增分 $\Delta u, \Delta v, \Delta w$ を次のように仮定する。すなわち， 面外方向の変位增分 $\Delta w$ には面積座標系で 3 次の多項 式を仮定し，面内方向の変位增分 $\Delta u, \Delta v$ には文献 6), 7)，と同様に面内の曲げ変形を考慮して曲率を表す項を 付加した次式を仮定する。

$$
\begin{aligned}
\Delta \boldsymbol{u} & =\left\{\begin{array}{c}
\Delta u \\
\Delta v
\end{array}\right\} \\
& =\boldsymbol{A}_{1} \cdot \boldsymbol{\alpha}_{1}+\boldsymbol{L}_{23} \cdot \boldsymbol{N}(r, s) \cdot \Delta \boldsymbol{\beta} \\
\Delta w & =\boldsymbol{A}_{2} \cdot \boldsymbol{\alpha}_{2} \ldots \ldots \ldots \ldots \ldots \ldots \ldots \ldots
\end{aligned}
$$

ここで,

$$
\begin{aligned}
& A_{1}=\left[\begin{array}{cccccc}
1 & \zeta_{1} & \zeta_{2} & \cdot & \cdot & \cdot \\
\cdot & \cdot & \cdot & 1 & \zeta_{1} & \zeta_{2}
\end{array}\right] \\
& \boldsymbol{A}_{2}=\left[\begin{array}{llllll}
1 & \zeta_{1} & \zeta_{2} & \zeta_{1} \zeta_{2} & \zeta_{2} \zeta_{3} & \zeta_{3} \zeta_{1}
\end{array}\right. \\
& \left.\zeta_{1} \zeta_{2}^{2}-\zeta_{2} \zeta_{1}^{2} \cdot \zeta_{2} \zeta_{3}^{2}-\zeta_{3} \zeta_{2}^{2} \zeta_{3} \zeta_{1}^{2}-\zeta_{1} \zeta_{3}^{2}\right] \\
& \alpha_{1}^{T}=\left\{\alpha_{1}, \alpha_{2}, \alpha_{3}, \alpha_{4}, \alpha_{5}, \alpha_{6}\right\} \\
& \alpha_{2}^{T}=\left\{\alpha_{7}, \alpha_{8}, \alpha_{9}, \alpha_{10}, \alpha_{11}, \alpha_{12}, \alpha_{13}, \alpha_{14}, \alpha_{15}\right\} \\
& N(r, s)=\left[\begin{array}{cc}
-2 r s & -3 r^{2} s \\
r^{2} & r^{3}
\end{array}\right] \\
& \Delta \boldsymbol{\beta}=\left\{\begin{array}{l}
\Delta \beta_{1} \\
\Delta \beta_{2}
\end{array}\right\}
\end{aligned}
$$

であり, $\boldsymbol{L}_{23}$ はFig. 11 に示す座標系 $\mathrm{O}_{2}$ と $\mathrm{O}_{3}$ との間の $(2$ $\times 2)$ の座標変換マトリックスであり”， $\Delta \beta$ は未定係数 である。また, Fig. 11 に示す解析モデルのひとつの帯 要素に属する三角形要素の未定係数 $\Delta \beta$ は共通のものを 用いる。

以上に述べたように試験体を理想化し，要素変位場を 
式（1），（2）に示すように仮定すれば，通常の有限要 素法の定式化に従うことで文献 4）と同様に増分型の平 衡方程式を導くことができる。ただし，節点変位べクト ルは次の自由度を持つことになる。

$$
\begin{aligned}
\Delta_{e} \boldsymbol{u}^{T}= & \left\{\Delta_{e} u_{1}, \Delta_{e} v_{1}, \Delta_{e} w_{1}, \Delta_{e} \theta_{x 1}, \Delta_{e} \theta_{y 1},\right. \\
& \Delta_{e} u_{2}, \Delta_{e} v_{2}, \Delta_{e} w_{2}, \Delta_{e} \theta_{x 2}, \Delta_{e} \theta_{y 2}, \\
& \Delta_{e} u_{3}, \Delta_{e} v_{3}, \Delta_{e} w_{3}, \Delta_{e} \theta_{x 3}, \Delta_{e} \theta_{y 3}, \\
& \left.\Delta_{e} \beta_{1}, \Delta_{e} \beta_{2}\right\} \ldots \ldots \ldots \ldots \ldots \ldots \ldots \ldots \ldots \ldots \ldots \ldots \ldots \ldots \ldots
\end{aligned}
$$

以下，鋼材の高温挙動をモデル化する仮定や平面応力 状態の構造用鋼材の熱弾塑性クリープ挙動構成式並びに 増分型の平衡方程式等を用いて，偏心圧縮荷重を受ける T形断面鋼柱の熱弾塑性クリープ座屈挙動解析を実行す ることができる。

T形断面鋼柱材はFig. 11 に示すように有限要素分割 を行い，有限要素内の積分点は板厚方向に層状に 6 分割 する。

また，初期面外たわみは ${ }_{g} Y$ 軸に対して逆対称形の次 式で仮定する。

$$
W_{0}\left({ }_{g} X,{ }_{g} Y\right)=\delta_{1} \cdot{ }_{g} Y / B \cdot \sin \left(2 \pi \cdot{ }_{g} X / L\right) \cdots \cdot(4)
$$

ここで， $L$ は柱材長 $390 \mathrm{~mm}, B$ は幅 $90 \mathrm{~mm}$ であり， $\delta_{1}$ は $L / 1000$ と仮定した。

鋼材の $\sigma-\varepsilon_{\rho}$ 曲線は， Т 形断面柱試験体を製作した鍓 板から採取した引張試験片の高温引張試験を行い, 結果 を次式で近似した。

$$
\sigma=c_{T}\left(a_{T}+\varepsilon_{p}\right)^{n_{T}}
$$

引張試験結果より求めた $\sigma-\varepsilon_{p}$ 曲線式の係数值を Table 4 に示す。ここで, $E_{R T}=2.1 \times 10^{4}\left(\mathrm{~kg} / \mathrm{mm}^{2}\right)$, $\sigma_{y R T}=36.9\left(\mathrm{~kg} / \mathrm{mm}^{2}\right), \nu=0.3$ である。Fig. 12 に $\sigma-\varepsilon$ 曲線の引張試験結果と式（5）による近似值とを示した。 単軸の高温クリープひずみ式は，既に文献 2) で用い

Table $4 \quad \sigma^{-} \varepsilon_{\rho}$ 曲線の諸係数値

\begin{tabular}{|c|c|c|c|c|}
\hline$T(\cdot C)$ & $B_{T} / B_{R T}$ & $C_{T / \sigma} / \sigma_{Y T}$ & $a_{T} / \varepsilon_{\nu R T}$ & $n_{T}$ \\
\hline 500 & 0.660 & 0.163 & 0.0115 & 1.561 \\
525 & 0.642 & 0.154 & 0.0098 & 1.358 \\
550 & 0.646 & 0.125 & 0.0056 & 1.061 \\
\hline
\end{tabular}

T: temperature, RT: room temperature

B:Young's modulus, $\sigma_{y}:$ yield strength, $\varepsilon_{y}=\sigma_{y} / \mathbb{B}$

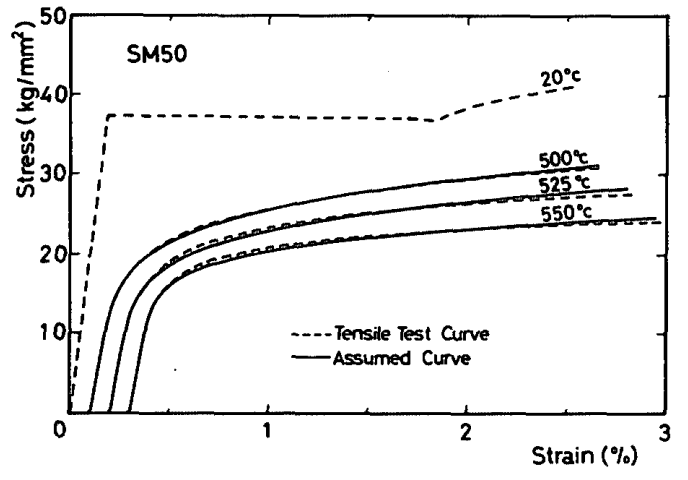

Fig. 12 試験体鋼材の単軸 $\sigma-\varepsilon$ 曲線
た SM 50 鋼材用の次式をここでも用いる。

$$
\varepsilon_{c}=10^{a} \cdot|\sigma|^{b} \cdot t^{c|\sigma|+d} \cdot \operatorname{sgn} \sigma
$$

ここで， $\varepsilon_{c}(\%)$ はクリープひずみ, $t$ (分) は時間, $\sigma\left(\mathrm{kg} / \mathrm{mm}^{2}\right)$ は応力であり, $a, b, c, d$ は Table 5 に 示す定数である。

また，ヒンジの摩擦による拘束曲げモ一メントも文献 2）と同様に作用モーメントの $5 \%$ とする。すなわち, 実験で用いた偏心距離 $e$ の 0.95 倍を解析用の偏心距離 として用いる。

なお，試験体のエンドプレートと試験体に取り付けら れた加力治具とを表現する鋼製ブロックの材質は， T形 断面柱材部分と同じ SM 50 A とする。

\section{3-2 計算結果}

Fig. 5，6に一定荷重試験の解析結果を，またFig. 7, 8 に変動荷重試験の解析結果をそれぞれ実線で示した。

一定荷重試験の Fig. 5，6においては，T=550 $\mathrm{C} ， e$ $=15 \mathrm{~mm}, \beta=0.3$ の場合のように実験結果と計算結果 の間に量的な差が見られるものがある。また実験温度が $500^{\circ} \mathrm{C}$ の場合は計算值は実験値より遅く崩壊する傾向に

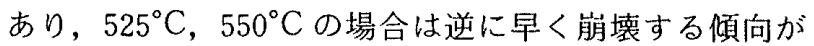
見られる。しかし，おおむね夷験結果と計算結果とは対 応している。

また, Fig. 7,8の変動荷重試験の場合も, $T=500^{\circ} \mathrm{C}$ の場合は荷重を階段状に上昇させた後の変位增加が実験 値に比較して小さい傾向を示しているが，計算結果は㬰 験結果とほぼ対応していると見ることができる。

このように本解析例では，若干の量的差異が見られる 例もあるが，計算結果はおおむね実験結果と一致してい る。

次に，Fig.13では，計算值と実験值の対応が最も悪 いと思われる $T=550^{\circ} \mathrm{C}, e=15 \mathrm{~mm}, \beta=0.3$ の場合を 解析例にして, T形断面鋼柱のクリープ座屈挙動の解析 結果に影響を与えると思われる諸因子のうち (a) 初期 たわみ量，(b) ピンの摩擦，(c) クリープひずみの影 響度を調べた。

Fig. 13-a は初期たわみ式（4）の最大振幅 $\delta_{1}$ のみを $L / 1000, L / 3000, L / 5000$ 之変化させた場合の計算結 果を，Fig. 13-b は実験治具のピンの摩擦を考慮して偏 心量 $e$ のみを $1.0 e, 0.95 e, 0.90 e$ 亡変化させた場合の 計算結果を，Fig. 13-cはクリープひずみ量の影響を調 べるために式（6）の $\sigma$ のみを $1.0 \sigma, 0.95 \sigma, 0.90 \sigma$ と 変化させた場合の計算結果を示している。

いずれの場合も解析結果にかなりの差が現れており， クリープ座屈挙動解析結果が各種の要因に敏感に影響さ れることが分かる。ちなみに，常温におけるピンの摩擦 係数は約 0.05〜0.1である。高温では，潤滑材として用 いた雲母が軟化する傾向にあるので，更に摩擦係数が増 大することも考えられる。また，本実験で用いた鋼は文 


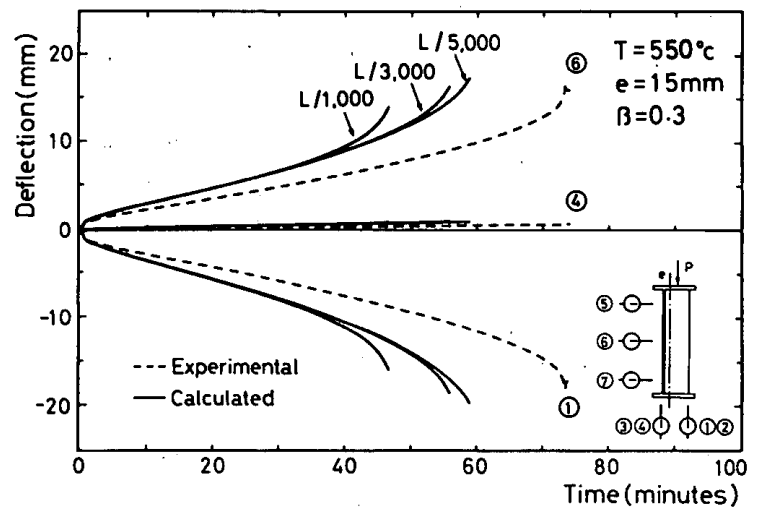

Fig.13-a 初期たわみの影響

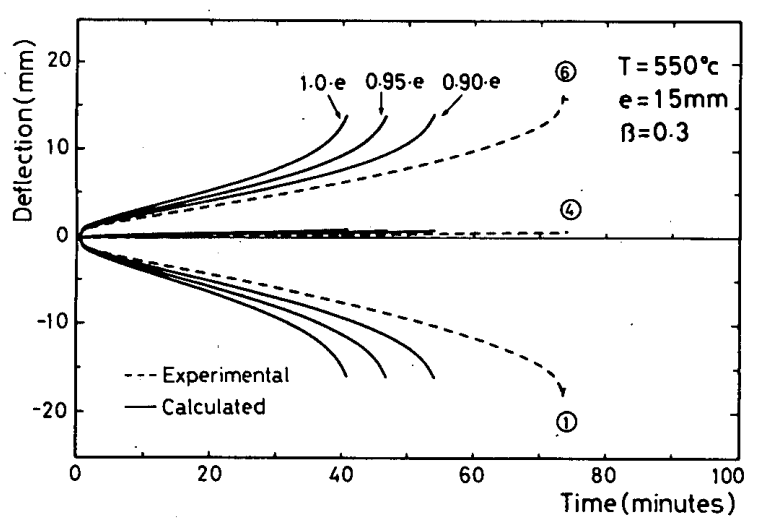

Fig. 13-b 偏心量の影響

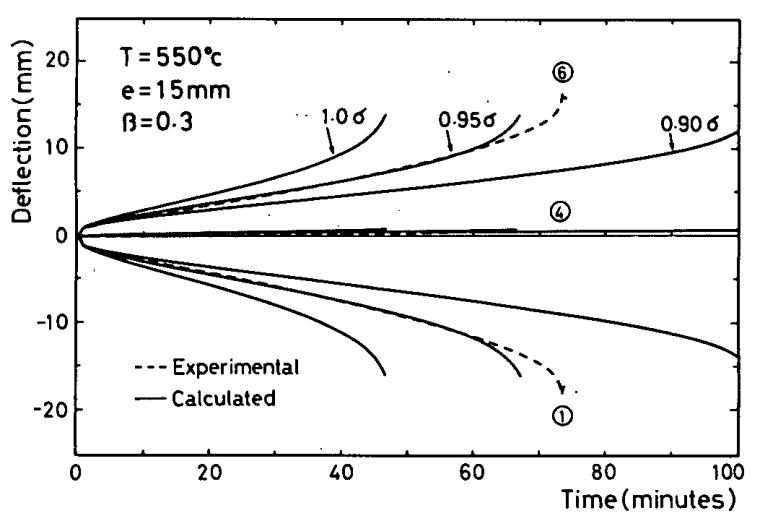

Fig. 13-c クリープ式の影響

Table 5 クリープ曲線の諸定数值

\begin{tabular}{|c|c|c|c|c|}
\hline \multirow{2}{*}{ TEMP. } & \multicolumn{4}{|c|}{ MATBRIAL CONSTANTS (SM50) } \\
\cline { 2 - 5 }$(\cdot \mathrm{C})$ & $\mathrm{a}$ & $\mathrm{b}$ & $\mathrm{c}$ & $\mathrm{d}$ \\
\hline 500 & $-0.5594 \times 10$ & $0.3387 \times 10$ & $0.1933 \times 10^{-1}$ & 0.1526 \\
525 & $-0.5512 \times 10$ & $0.3488 \times 10$ & $0.2624 \times 10^{-1}$ & 0.1484 \\
550 & $-0.4828 \times 10$ & $0.3126 \times 10$ & $0.3583 \times 10^{-1}$ & 0.1174 \\
\hline
\end{tabular}

献 2) で示したクリープ定数（Table 5）を決定した鋼 材と鋼種は同じ SM 50 であるが，同一の鋼板より採取 されたものではないので若干，組成や力学的性質が巽 なっている。したがって，クリープについても多少の差 異が存在するものと思われる。
Fig.13の結果と本実験の誤差とを考虑すると, Fig. 5，6，7，8で示した計算結果は実験挙動を良く説明 していると解釈することができ，本章で用いた計算方法 および仮定した材料の挙動は有効であると言うことがで きる。

\section{$\S 4$. 結 語}

本論文では, 各種の偏心距離と軸力比のもとで $\mathrm{T}$ 形断 面鋼柱部材の高温クリープ座屈実験を行い実験結果を得 た。また，平板要素を用いた有限要素法熱弾塑性クリー プ解析により奏験のシミュレーションを行い, 解析法の 妥当性の確認を行った。

本実験は，高温時の局部座屈が原因で起こる鋼柱のク リープ座屈挙動を詳細に調へる実験としては最初の試み であり，高温弾塑性クリープ域の局部座屈により柱部材 に崩壊が起こる場合の実験的資料を得ることができた。 このような実験資料は今後，鋼構造建築物の合理的な耐 火設計法の発展のために役立つものと思われる。

また, 本論文で用いた解析法は, 素材の特性, 解析モ デル，解析理論に関するいくつかの仮定に基づいている が，計算結果は㬰験結果とおおむね一致するものであっ た。このことは, 本論文で用いた解析方法および素材デー 夕の有効性を示すものである。

本研究は, 高温時において局部座屈を伴う鋼柱のク リープ座屈挙動を詳細に調べるための試みの一つである が，ここで示された実験は限られた試験条件におけるも のであり，局部座屈を伴う鋼柱のクリープ座屈挙動の全 貌が明らかにされた訳ではない。局部座屈を伴う鋼柱の クリープ変形挙動をさらに明らかにするため,なお一層 多くの実験的，解析的研究が必要である。

\section{参考文献}

1) Furumura, F. and Ave, T. : Creep Buckling of Steel Columns at High Temperatures, Part 1 Development of Creep Buckling Test Apparatus, Trans, of A.I.J. No. 344 , pp. $164 \sim 173,1984.10$

2) Furumura, F., Ave, T., and Kim, W, J. : Creep Buckling of Steel Columns at High Temperatures, Part 2 Creep Buckling Test and Numerical Analysis, J. of Structural and Construction Engineering, Trans. of A. I. J., No.361, pp. 142 151, 1986. 3

3）小林秀夫, 上杉秀樹, 斉藤 光, 大内富夫, 古平章夫, 増田秀昭, 中村賢一：H形鋼部材の火災時の変形性能に 関する実験（その 1 実験概要）（その 2 実験結果の検 討), 日本建築学会関東支部研究報告集, pp. $377 \sim 384$, 昭和 61 年度

4) 古村福次郎, 右田健児, 安部武雄, 岡部 猛, 金和中 : 面内王縮荷重を受ける単一鋼平板の熱弾塑性クリープ 座屈挙動解析, 日本建築学会構造系論文報告集, 第 394 号, pp. 141 151, 昭和 63 年 12 月

5）金子洋文：有限要素法による鋼構造部材構成板要素の火 
災時の力学性状に関する解析法, 日本建築学会構造系諭 文報告集，第 406 号，pp. 93 102，1989 年 12 月

6）山田嘉明，高塚公郎：平面変形モデルによるはりおよび 柱の弾塑性解析, 日本鋼構造協会第 7 回大会研究集会, マトリックス構造解析法研究発表論文集, pp. 307 316, 昭和 48 年 (1973)

7) 藤本盛久, 和田 章, 彦根 茂: 板の弾塑性解析一形鋼 の局部座屈解析, 日本鋼棈造協会第 9 回大会研究集会, マトリックス構造解析法研究発表論文集, pp. 221 226, 昭和 50 年
8) 岡部猛, 古村福次郎, 安部武雄, 篗原保三：T形断面 鋼柱のクリープ坐屈実験, 日本建築学会大会学術講演梗 概集 (九州)，pp. 1045 1046，1989 年度 10 月

9）岡部 猛, 古村福次郎, 右田健児, 田部桂一郎：T形断 面鋼柱の高温クリープ変形挙動解析, 日本建築学会中国 · 九州支部研究報告, 第 8 号, pp. 201 - 204, 平成 2 年 3 月

(1990 年 7 月 9 日原稿受理, 1990 年 12 月 5 日採用決定) 